\title{
Features of randomised trials designed by the NPEU Perinatal Trials Service during Adrian Grant's directorship
}

\author{
Diana Elbourne
}

\begin{abstract}
Adrian Grant pioneered methodological innovations in the randomised trials organised by the Perinatal Trials Service established at the national Perinatal Epidemiology Unit in Oxford, UK. This Commentary discusses these innovations, and shows the wide range of trials designed under his directorship.
\end{abstract}

\section{Background}

In his article recording Adrian Grant's pioneering use of evidence synthesis in perinatal medicine between 1980 and 1992, Iain Chalmers [1] quoted from a 1984 letter published in The Lancet which Iain and I had co-authored with Adrian [2]. In that letter we alluded to some of the additional principles - beyond the need for systematic review of existing evidence which became methodological features of the wide range of randomised trials organised by the Perinatal Trials Service (PTS) established at the national Perinatal Epidemiology Unit (NPEU). The trials are listed in Appendix 1.

\section{Methodological features \\ Appropriate size}

Our 1984 letter concluded with a warning that, to avoid the dangers of false inferences from non-randomised comparisons and small randomised trials, many perinatal controlled trials require sample sizes larger than any single unit can generate within a reasonable length of time. Although one centre was sufficient to obtain sufficient sample sizes to address some questions, for other questions, multicentre (often international) trials were needed.

\section{Secure, random allocation}

The NPEU PTS used a variety of contextually appropriate methods for secure random allocation sequentially numbered sealed opaque envelopes, sequentially numbered drug vials, and central random allocation when there was sufficient time to make a call and where reasonable telecommunications existed.

\section{Appropriate design}

Most of the trials used two-armed, individually randomised designs. Where appropriate, more complex designs were employed, including factorial trials and a cluster randomised trial.

\section{Involving the views of care-givers and patients and their} families

The PTS recognised that our work needed to address questions considered important by caregivers and families, so they were involved in deciding which questions to address, trial design and conduct, and dissemination of results. Taking account of families meant that many PTS trials investigated long term outcomes, such as pain, dyspareunia and incontinence for women, and disability for children. 


\section{Facilitating infrastructure}

A programme of randomised trials to support these methodological underpinnings needed an infrastructure and the PTS was established in 1982 "to provide a service to busy clinicians who wish to mount large simple-in-design randomized trials...[aiming] to identify moderate, but clinically useful, effects of promising treatments for the most important problems in perinatal care" [3].

The PTS had a flexible five-person core staff and others employed to work on specific trials. This continuity of staff enabled us to build standard operating systems. International trials needed particularly careful coordination, and the provision of trials materials in a number of languages. The eclampsia trial [4], for example was preceded by a pilot study in Argentina, with materials in Spanish.

\section{Adrian Grant's legacy for perinatal trials}

Over the years that Adrian Grant designed perinatal trials in the NPEU, the above methodological innovations and others are listed in the Table 1 below.

Adrian continued to support trials in Aberdeen after his move to direct the Health Services Research Unit there (https://www.abdn.ac.uk/hsru) in 1994, and then for the National Institute for Health Research (http:// www.nihr.ac.uk).

\section{Conclusions}

Many people are grateful for Adrian's methodological rigor, his innovative approaches, and his generosity of support, mentoring and teaching. The lives of many babies and their families have been improved by Adrian's pioneering work in perinatal trials, and the PTS that Adrian created has gone on to become a highly successful Clinical Trials Unit (https:// www.npeu.ox.ac.uk/ctu).

Table 1 Adrian Grant's methodological innovations

- Identification and prioritisation of important questions

- Systematic reviews

- Alliance of patients, carers, and clinicians

- Efficient trial conduct

- Secure randomisation

- Appropriate design, outcomes, and size

- Support for participants

- Newsletters

- Integral economic evaluation

- Embedded methodological research

- Long term follow up

- Feedback of trial results

\section{Appendix}

Randomised trials designed by the NPEU Perinatal Trials Service during Adrian Grant's directorship

Table 2 Antenatal interventions

- Chorion villus sampling vs amniocentesis [5]

- Cervical cerclage $[6,7]$

- Breast shells and Hoffman's exercises [8]

- Formal fetal movement counting [9]

- Placental grading by ultrasonography [10]

- Anti-convulsants for eclampsia [4]

- Low dose aspirin [11, 12]

- Fish-oil supplementation [13]

• 'Know your Midwife' [14]

- Social support [15]

Table 3 Intrapartum interventions

- Dublin intrapartum fetal heart rate monitoring [16-19]

- Vacuum extraction vs forceps (Portsmouth operative delivery) [20-22]

- Vacuum extraction: different cups [23]

- Fetal scalp electrode [24]

- Perineal management (Berkshire) $[25,26]$

- Perineal suture (Southmead) [27]

- Catgut for the repair of perineal trauma [28, 29]

- Ipswich perineal repair [30-33]

Table 4 Postnatal interventions

- Pelvic floor exercises [34]

- Salt and Savlon bath concentrate [35]

- Ultrasound and pulsed electromagnetic energy treatment for perineal trauma $[36,37]$

Table 5 Neonatal interventions

- Neonatal ventriculomegaly [38, 39]

- Dexamethasone [40, 41]

- Prophylactic ethamsylate $[42,43]$

- Surfactant [44]

- Extracorporeal membrane oxygenation [45-53] 


\section{Author's contribution}

$\mathrm{DE}$ is the sole contributor. The author read and approved the final manuscript

\section{Ethics approva \\ Not applicable.}

\section{Consent for publication}

Not applicable.

\section{Competing interests}

The authors declare that they have no competing interests.

\section{Publisher's Note}

Springer Nature remains neutral with regard to jurisdictional claims in published maps and institutional affiliations.

Received: 27 May 2018 Accepted: 2 July 2018

Published online: 09 July 2018

\section{References}

1. Chalmers I. Adrian Grant's pioneering use of evidence synthesis in perinatal medicine, 1980-1992. Reprod Health. 2018;15:79.

2. Chalmers I, Elbourne D, Grant A. Phenobarbitone and periventricular haemorrhage. Lancet. 1984;1:286.

3. Grant AM. Rationale for and work of the perinatal trials service. Early Hum Dev. 1992;29:305-8.

4. The Eclampsia Trial Collaborative Group. Which anticonvulsant for women with eclampsia? Evidence from the collaborative eclampsia trial. Lancet. 1995;345:1455-63.

5. MRC Working Party on the Evaluation of Chorion Villus Sampling. Medical Research Council European trial of chorion villus sampling. Lancet. 1991;337:1491-9.

6. Chalmers I, Grant AM. Cervical cerclage. Br J Obstet Gynaecol. 1982;89(7): 497-8.

7. Rush RW, Isaacs S, McPherson K, Jones L, Chalmers I, Grant AM. A randomized controlled trial of cervical cerclage in women at high risk of spontaneous preterm delivery. Br J Obstet Gynaecol. 1984;91(8):724-30.

8. Alexander JM, Grant AM, Campbell MJ. Randomized controlled trial of breast shells and Hoffman's exercises for inverted and non-protractile nipples. Br Med J. 1992;304:1030-2.

9. Grant AM, Elbourne DR, Valentin L, Alexander S. Routine formal fetal movement counting and risk of antepartum late death in normally-formed singletons. Lancet. 1989:2:345-9.

10. Proud J, Grant AM. Third trimester placental grading by ultrasonography as a test of fetal wellbeing. Br Med J. 1987:294:1641-4.

11. CLASP (Collaborative Low-dose Aspirin Study in Pregnancy) Collaborative Group. CLASP: a randomised trial of low-dose aspirin for the prevention and treatment of pre-eclampsia among 9364 pregnant women. Lancet. 1994;343:619-29.

12. Rotchell YE, Cruickshank JK, Phillips Gay M, Griffiths J, Stewart A, Farrell B, Ayers S, Hennis A, Grant AM, Duley L, Collins RE. Barbados low dose aspirin study in pregnancy (BLASP): a randomised trial for the prevention of preeclampsia and its complications. Br J Obstet Gynaecol. 1998;105:286-92.

13. Olsen SF, Sorensen JD, Secher NJ, Hedegaard M, Henriksen TB, Hansen HS, Grant AM. Randomized controlled trial of the effect of fish-oil supplementation on pregnancy duration. The lancet. 1992 1992;339(8800):1003-7

14. Flint C, Poulengeris P, Grant AM. The 'Know your Midwife' scheme - a randomised trial of continuity of care by a team of midwives. Midwifery. 1989:5:11-6.

15. Oakley A, Rajan L, Grant AM. Social support and pregnancy outcome. Br J Obstet Gynaecol. 1990;97:155-62

16. MacDonald D, Grant AM, Sheridan-Pereira M, Boylan P, Chalmers I. The Dublin randomized controlled trial of intrapartum fetal heart rate monitoring. Am J Obstet Gynecol 1985. 1985;152(5):524-39.

17. Garcia J, Corry M, MacDonald D, Elbourne DR, Grant AM. Mothers' views of continuous electronic fetal heart monitoring and intermittent auscultation in a randomized controlled trial. Birth. 1985;12(2):79-86.

18. Grant AM. Some answers to questions raised about the Dublin trial. Birth. 1986;13(4):255-6.
19. Grant AM, O'Brien N, Joy M-T, Hennessy E, MacDonald D. Cerebral palsy among children born during the Dublin randomized trial of intrapartum monitoring. Lancet 1989;ii(8674):1233-1236.

20. Vacca A, Grant AM, Wyatt G, Chalmers I. Portsmouth operative delivery trial: a comparison of vacuum extraction and forceps delivery. Br J Obstet Gynaecol. 1983;90(12):1107-12.

21. Garcia J, Anderson J, Vacca A, Elbourne DR, Grant AM, Chalmers I. Views of women and their medical and midwifery attendants about instrumental delivery using vacuum extraction and forceps. J Psychosom Obstet Gynaecol. 1985;4:1-9.

22. Carmody F, Grant AM, Mutch LM, Vacca A, Chalmers I. Follow up of babies delivered in a randomized controlled comparison of vacuum extraction and forceps delivery. Acta Obstet Gynecol Scand. 1986;65(7):763-6.

23. Carmody F, Grant AM, Somchiwong M. Vacuum extraction: a randomized controlled comparison of the new generation cup with the original bird cup. J Perinat Med. 1986;14:95-100.

24. Needs L, Grant AM, Sleep J, Ayers S, Henson G. A randomized controlled trial to compare three types of fetal scalp electrode. Br J Obstet Gynaecol. 1992;99:302-6.

25. Sleep J, Grant AM, Garcia J, Elbourne DR, Spencer JAD, Chalmers I. West Berkshire perineal management trial. Br Med J. 1984;289:587-90.

26. Sleep J, Grant AM. West Berkshire perineal management trial: three year follow up. Br Med J. 1987:295:749-51.

27. Mahomed K, Grant AM, Ashurst H, James D. The Southmead perineal suture study. A randomized comparison of suture materials and suturing techniques for repair of perineal trauma. Br J Obstet Gynaecol 1989 1989; 96(11):1272-1280

28. Spencer JAD, Grant AM, Elbourne DR, Garcia J, Sleep J. A randomized comparison of glycerol-impregnated chromic catgut with untreated chromic catgut for the repair of perineal trauma. Br J Obstet Gynaecol. 1986;93:426-30

29. Grant AM, Sleep J, Ashurst H, Spencer JAD. Dyspareunia associated with the use of glycerol-impregnated catgut to repair perineal trauma report of a three-year follow-up study. Br J Obstet Gynaecol. 1989;96:741-3.

30. Mackrodt C, Gordon B, Fern E, Ayers S, Truesdale A, Grant AM. The Ipswich childbirth study: 2. A randomised comparison of polyglactin 910 with chromic catgut for postpartum perineal repair. Br J Obstet Gynaecol. 1998:105(4):441-5.

31. Gordon B, Mackrodt C, Fern E, Truesdale A, Ayers S, Grant AM. The Ipswich childbirth study: 1. A randomised evaluation of two stage postpartum perineal repair leaving the skin unsutured. Br J Obstet Gynaecol. 1998;105(4):435-40

32. Grant AM, Gordon B, Mackrodt C, Fern E, Truesdale A, Ayers S. The Ipswich childbirth study: one year follow-up of alternative methods used in perineal repair. Br J Obstet Gynaecol. 2001;108:34-40.

33. Petrou S, Gordon B, Mackrodt C, Fern E, Ayers S, Grant AM, Truesdale A McCandlish R. How cost-effective is it to leave perineal skin unsutured? British J Midwifery. 2001;9(4):209-14.

34. Sleep J, Grant AM. Pelvic floor exercises in post-natal care. Midwifery. 1987;3:158-64.

35. Sleep J, Grant AM. Effects of salt and Savlon bath concentrate postpartum. Nurs Times. 1988:84:55-7.

36. Everett T, Mclntosh J, Grant AM. Ultrasound therapy for persistent postnatal perineal pain and dyspareunia: a randomised placebo-controlled trial. Physiotherapy. 1992;78:263-7.

37. Grant AM, Sleep J, McIntosh J, Ashurst H. Ultrasound and pulsed electromagnetic energy treatment for perineal trauma. A randomized placebo-controlled trial. Br J Obstet Gynaecol. 1989;96:434-9.

38. Ventriculomegaly Trial Group. Randomised trial of early tapping in neonatal posthaemorrhagic ventricular dilatation. Arch dis child. 1990. 1990:65(1):3-10

39. Ventriculomegaly Trial Group. Randomised trial of early tapping in neonatal posthaemorrhagic ventricular dilatation: results at 30 months. Arch dis child 1994. 1994;70(2):F129-36.

40. Collaborative Dexamethasone Trial Group. Dexamethasone therapy in neonatal chronic lung disease: an international placebo controlled trial. Pediatrics. 1991:88:421-7.

41. Jones RAK, Wincott E, Elbourne DR, Grant AM. Controlled trial of dexamethasone in neonatal chronic lung disease: a 3-year follow-up. Pediatrics. 1995;96:897-906. 
42. The EC Ethamsylate Trial Group. The EC randomised controlled trial of prophylatic ethamsylate for very preterm neonates: early mortality and morbidity. Arch Dis Child. 1994;70:F201-5.

43. Elbourne DR, Ayers S, Dellagrammaticas $H$, Johnson A, Leloup M, Lenoir-Piat S. EC Ethamsylate trial group. Randomised controlled trial of prophylactic ethamsylate: follow up at 2 years of age. Arch Dis Child. 2001;84:F183-7.

44. OSIRIS Collaborative Group. Early versus delayed neonatal administration of a synthetic surfactant - the judgment of OSIRIS. Lancet. 1992;340:1363-9.

45. UK Collaborative ECMO Trial Group. UK collaborative randomised trial of neonatal extracorporeal membrane oxygenation. Lancet. 1996;348:75-82.

46. Howard S, Mugford M, Normand C, Elbourne DR, Grant AM, Field DJ, Johnson A. A cost effectiveness analysis of neonatal ECMO using existing evidence. Int J Technol Assess Health Care. 1996;12:80-92.

47. Snowdon C, Garcia J, Elbourne DR. Making sense of randomization: responses of parents of critically ill babies to random allocation of treatment in a clinical trial. Soc Sci Med. 1997;45:1337-55.

48. Snowdon C, Garcia J, Elbourne DR. Reactions of participants to the results of a randomised controlled trial: exploratory study. Br Med J. 1998;317:21-6.

49. Snowdon C, Elbourne DR, Garcia J. Zelen randomization: attitudes of parents participating in a neonatal clinical trial. Control Clin Trials. 1999;20:149-71.

50. Bennett CC, Johnson A, Field DJ, Elbourne DR. For the UK collaborative ECMO trial group. UK collaborative randomised trial of neonatal extracorporeal membrane oxygenation: follow-up to age 4 years. Lancet. 2001;357:1094-6.

51. Petrou S, Edwards L. Cost-effectiveness analysis of neonatal extracorporeal membrane oxygenation based on four year results from the UK collaborative ECMO trial. Arch Dis Child. 2004;89:F263-F8.

52. Petrou S, Bischof M, Bennett CC, Elbourne DR, Field DJ, McNally H. Costeffectiveness of neonatal extracorporeal membrane oxygenation based on 7 year results from the United Kingdom collaborative ECMO trial. Pediatrics. 2006;117:1640-9.

53. McNally H, Bennett CC, Elbourne DR, Field DJ. For the UK collaborative ECMO trial group. United Kingdom collaborative randomized trial of neonatal extracorporeal membrane oxygenation: follow-up to age 7 years. Pediatrics. 2006;117:845-54.

\section{Ready to submit your research? Choose BMC and benefit from:}

- fast, convenient online submission

- thorough peer review by experienced researchers in your field

- rapid publication on acceptance

- support for research data, including large and complex data types

- gold Open Access which fosters wider collaboration and increased citations - maximum visibility for your research: over $100 \mathrm{M}$ website views per year

At BMC, research is always in progress.

Learn more biomedcentral.com/submissions 